\title{
TISSUE CONCENTRATIONS OF ENDOTHELINS AND FUNCTIONAL EFFECTS OF ENDOTHELIN- RECEPTOR ACTIVATION IN HUMAN ARTERIES AND VEINS
}

Peter Holm, MD

Anders Franco-Cereceda, MD, PhD
In the present study, the tissue content and functional effects of endothelin-1 and endothelin-3 were examined in human vessels of importance in coronary bypass operations. Human coronary arteries (i.e., the left anterior descending coronary artery) were obtained from eight cardiac valve donors within 6 hours after death, pulmonary arteries were perioperatively obtained from 15 patients operated on because of lung tumors, and internal thoracic arteries and great saphenous and cephalic veins were obtained at coronary bypass operations from a total of 28 patients. Endothelin-1 and endothelin-3 content was quantified by radioimmunoassay. For functional experiments, the vessels were mounted in organ baths for recordings of isometric contractions in response to endothelin-1, endothelin-3, and the endothelin ${ }_{A}-$ receptor agonist sarafotoxin 6c. In all vessels investigated, the endothelin-1 content was higher than that of endothelin-3. The highest levels were found in the left anterior descending coronary artery, followed in declining order by the internal thoracic artery, pulmonary artery, saphenous vein, and cephalic vein. Endothelin-1 contracted all vessels in a concentration-dependent fashion. This effect was enhanced in the left anterior descending and internal thoracic arteries by inhibition of nitric oxide and prostaglandin formation. The contractile effect was attenuated in a concentration-dependent fashion in all vessels by incubation with the endothelin ${ }_{\mathrm{A}}$-receptor blocker BQ-123. Furthermore, contractions evoked by endothelin-1 in the left anterior descending coronary and pulmonary arteries were antagonized by the combined endothelin ${ }_{\mathrm{A}^{-}}$and endothelin $\mathrm{B}_{\mathrm{B}^{-}}$-receptor blocker bosentan. Endothelin-3 contracted the left anterior descending coronary and pulmonary arteries and the saphenous vein, but not the internal thoracic artery, in a BQ-123-sensitive fashion. However, after inhibition with nitric oxide or prostaglandin, endothelin-3 also contracted the internal thoracic artery, and the response in the left anterior descending coronary artery was enhanced. Sarafotoxin $6 c$ evoked a BQ-123-sensitive contraction of the left anterior descending coronary artery. It is concluded that endothelin ${ }_{A}$ receptors mediate the major portion of the vasoconstriction observed on exposure to endothelin-1, endothelin-3, and sarafotoxin $6 \mathrm{c}$ in the left anterior descending coronary, pulmonary, and internal thoracic arteries and the saphenous vein. Furthermore, endothelin ${ }_{\mathrm{B}}$-receptor activation, with subsequent formation of nitric oxide or prostaglandin (or both), counteracts the vasoconstrictor response to endothelin in the left anterior descending coronary and internal thoracic arteries, but not in the pulmonary artery or saphenous vein. The present findings therefore suggest that endothelin ${ }_{\mathrm{A}}$-receptor antagonism might prove beneficial in preventing possible endothelin-induced coronary graft spasm. (J Thorac Cardiovasc Surg 1996;112:264-72)
From the Department of Thoracic Surgery, Karolinska Hospital, Stockholm, Sweden.

Supported by grants from the Swedish Medical Research Council, the Heart and Lung Foundation, the Wiberg Foundation, the Wallenberg Foundation, the Thuring Foundation, the Swedish Society for Medicine, the Salus Foundation, and funds from the Karolinska Institute.
Received for publication July 20, 1995; revisions requested Oct. 9, 1995; revisions received Nov. 17, 1995; accepted for publication Jan. 3, 1996.

Address for reprints: Anders Franco-Cereceda, MD, PhD, Department of Thoracic Surgery, Karolinska Hospital, 17176 Stockholm, Sweden.

Copyright (c) 1996 by Mosby-Year Book, Inc.

$0022-5223 / 96 \$ 5.00+0 \quad \mathbf{1 2 / 1 / 7 1 6 0 1}$ 
T he endothelium is involved in the regulation of local vascular tone through release of both vasodilator and vasoconstrictor substances. ${ }^{1}$ Experiments showing potent vasoconstrictor effects of media obtained from cultured aortic endothelial cells suggested the existence of an endothelium-derived vasoconstrictor substance. ${ }^{2}$ The endothelium was later shown to synthesize the vasoactive peptide endothelin (ET) through enzymatic cleavage of the propeptide big ET. ${ }^{3}$ Studies have revealed a group of ET isopeptides named ET-1, ET-2, and ET-3. ${ }^{4}$ ET has been shown to evoke a variety of effects in the cardiovascular system, including vasoconstriction, ${ }^{3}$ vasodilatation, ${ }^{5,6}$ and positive inotropic and chronotropic actions, ${ }^{7,8}$ as well as negative inotropic effects. ${ }^{9}$ The variability of the effects of the three isopeptides in different vascular beds indicates the existence of multiple ET receptor subtypes. Thus the vascular effects of ET are mediated through interaction with putative $\mathrm{ET}_{\mathrm{A}}$ and $\mathrm{ET}_{\mathrm{B}}$ receptors. The $\mathrm{ET}_{\mathrm{A}}$ receptor is selective for ET-1 and causes vasoconstriction, whereas the $\mathrm{ET}_{\mathrm{B}}$ receptor is nonselective for the ET isopeptides and mediates vasodilatation. ${ }^{10}$ Recent reports in addition suggest the existence of $\mathrm{ET}_{\mathrm{B}}$ receptor subtypes: the $\mathrm{ET}_{\mathrm{B} 1}$ receptor on the endothelium mediates endotheliumdependent vasodilatation; the $\mathrm{ET}_{\mathbf{B} 2}$ receptor on smooth muscle cells causes vasoconstriction. ${ }^{11,12} \mathrm{~A}$ family of snake venom peptides, the sarafotoxins, show a remarkable structural resemblance to ET and act on the same receptor as ET. ${ }^{13}$ Among these peptides, sarafotoxin $6 \mathrm{c}$ is considered to activate $\mathrm{ET}_{\mathrm{B}}$ receptors. ${ }^{11,13}$

A variety of pathophysiologic disorders are associated with increased circulating plasma levels of ET. It was recently demonstrated that the concentration of ET in the coronary sinus is increased during coronary bypass operations, ${ }^{14,15}$ although the mechanism of this release remains unclear. ${ }^{15}$ Furthermore, ET is a potent constrictor of human coronary arteries $^{16}$ and of vessels used in coronary revascularization, ${ }^{17}$ whereas ET causes a tone-dependent vasoconstriction or vasodilatation of pulmonary arteries. ${ }^{18}$ In the present study, therefore, a comparison of the functional effects of ET-1 and ET-3 on human coronary (i.e., left anterior descending [LAD]), pulmonary (PA), and internal thoracic (ITA) arteries and great saphenous vein (SV) in vitro has been made. To further evaluate the influence of $\mathrm{ET}_{\mathrm{B}}$-receptor activation, we studied the effects of sarafotoxin $6 \mathrm{c}$ on the LAD and PA. In addition, the tissue content of ET-1 and ET-3 in these vessels and in the cephalic vein $(\mathrm{CV})$ has been determined.

\section{Methods}

This study was approved by the Ethics Committee of the Karolinska Hospital.

Functional experiments. Coronary arteries with an inner diameter of 0.8 to $1.2 \mathrm{~mm}$ (segments 7 and 8 of the LAD according to the American Heart Association Committee Report, 1975) were obtained within 6 hours after death from eight cardiac valve donors (five men and three women, $33 \pm 7$ years of age) with total cerebral infarction resulting from intracranial bleeding or trauma (or both). PAs of a similar size were obtained from 15 patients undergoing operations for lung tumors (10 men and five women, $67 \pm 3$ years of age). Distal ITAs and SVs were obtained from 25 patients undergoing coronary artery bypass operations ( 16 men and nine women, $66 \pm 2$ years of age). All vessels ( 1 to $2 \mathrm{~mm}$ in length) were dissected out under a microscope and mounted in $2 \mathrm{ml}$ organ baths on two L-shaped holders (diameter $0.3 \mathrm{~mm}$ ). A resting tension of $10 \mathrm{mN}$ was then applied by adjusting one of the metal holders. The other holder was connected to a Grass polygraph model 7B (Grass Instrument Co., West Warwick, R.I.) for recordings of isometric tension. The resting tension was chosen on the basis of preliminary experiments in which reproducible contractions were obtained at this resting tension. ${ }^{16}$ The vessels were kept in Tyrode's solution ( $\mathrm{pH} \mathrm{7.4)} \mathrm{of} \mathrm{the} \mathrm{following} \mathrm{composition} \mathrm{(in} \mathrm{milli-}$ moles per liter): $\mathrm{NaCl} 137, \mathrm{KCl} 2.7, \mathrm{CaCl}_{2} 1.8, \mathrm{MgCl}_{2} 1.05$, $\mathrm{NaHCO}_{3}$ 11.9, $\mathrm{NaH}_{2} \mathrm{PO}_{4}$ 0.42, and glucose 5.6. The Tyrode's solution was aerated with $95 \%$ oxygen and $5 \%$ carbon dioxide at $37^{\circ} \mathrm{C}$. After 60 minutes of equilibration during which the resting tension was adjusted to compensate for the spontaneous decline in arterial tension, circular contractions were induced by Tyrode's solution in which the $\mathrm{NaCl}$ had been replaced with equimolar amounts of $\mathrm{KCl}$ to give a final $\mathrm{K}^{+}$concentration of 127 $\mathrm{mmol} / \mathrm{L}$. Only vessels responding with two reproducible contractions to $\mathrm{K}^{+}$exposure were used, giving a total of 31 LADs, 47 PAs, 29 ITAs, and 30 SVs. Each experimental procedure was performed in vessels from at least five patients. ET-1, ET-3, sarafotoxin $6 \mathrm{c}$, or the $\mathrm{ET}_{\mathrm{B}}$-receptor agonist $\mathrm{Ala}{ }^{1,3,11,15} \mathrm{ET}-1^{10}$ was added to the organ baths either at single concentrations or in a cumulative fashion. The functional effects of these agents were studied under control conditions and after $\mathrm{ET}_{\mathrm{A}^{-}}$-receptor blockade using BQ- $123^{19}$ or combined $\mathrm{ET}_{\mathrm{A}}$ and $\mathrm{ET}_{\mathrm{B}}$ blockade using bosentan. ${ }^{12}$ In addition, the effects of inhibition of prostaglandin and nitric oxide formation were evaluated by incubating the vessels for 1 hour with the cyclooxygenase inhibitor indomethacin $\left(10^{-5} \mathrm{~mol} / \mathrm{L}\right)$ and the nitric oxidesynthase inhibitor $\mathrm{N}^{\mathrm{g}}$-monomethyl-L-arginine (L-NMMA; $10^{-4} \mathrm{~mol} / \mathrm{L}$ ), which were thereafter present throughout the experiments. ${ }^{18}$ Whereas BQ-123 and bosentan did not influence basal contractile tone per se, pretreatment with indomethacin and L-NMMA evoked a minor, but inconsistent, increase in resting tension.

Tissue determination of ET-1 and ET-3. Vessels were obtained from the above-mentioned patients and, in addition, CV specimens were obtained from another two 
Table I. Tissue content of ET-1 and ET-3 in some human vessels

\begin{tabular}{lcccc}
\hline & $E T-1$ & $E T-3$ & NPY & CGRP \\
\hline LAD & $1.14 \pm 0.13$ & $0.27 \pm 0.05$ & $9.7 \pm 1.33$ & $2.48 \pm 0.17$ \\
IMA & $1.07 \pm 0.18$ & $0.18 \pm 0.02$ & $2.67 \pm 0.5$ & $1.02 \pm 0.16$ \\
PA & $0.22 \pm 0.06$ & $0.17 \pm 0.03$ & $0.44 \pm 0.07$ & ND \\
SV & $0.21 \pm 0.02$ & $0.05 \pm 0.01$ & $4.62 \pm 1.14$ & $0.22 \pm 0.03$ \\
CV & $0.17 \pm 0.03$ & $0.07 \pm 0.03$ & ND & $0.17 \pm 0.02$ \\
\hline
\end{tabular}

For comparison the concentrations of neuropeptide $\mathrm{Y}(N P Y)$ and calcitonin gene-related peptide (CGRP) have been determined. Levels are expressed as picomoles per gram and given as means \pm standard error of the mean ( $n=2$ to 22 in each group).

ND, Not determined.

patients (two women; 71 and 75 years old). The vessels were frozen on Dry Ice and weighed. For extraction of ET-1- and ET-3-like immunoreactivity, the samples were heated at $95^{\circ} \mathrm{C}$ in water for 10 minutes, homogenized, and centrifuged. With this extraction the recovery of ET in plasma is greater than $80 \% .^{20}$ The supernatants were lyophilized and the content of ET-like immunoreactivity was determined by radioimmunoassay with two different antisera: ET-1 was determined by an ET-1 antiserum raised against ET-1 in rabbits (the cross-reactivity to ET-3 was $<8 \%$ ); ET-3 was determined with a commercially available antiserum, RAS 6911 (Peninsula, Belmont, $\mathrm{Ca}-$ lif.), with less than $0.1 \%$ cross-reactivity to ET-1. None of the antisera used showed any cross-reactivity $(<0.1 \%)$ to a variety of other peptides tested, including neuropeptide $\mathrm{Y}$, angiotensins I, II, and III, neurokinin A, and calcitonin gene-related peptide. Human ET-1 or ET-3 labeled with iodine 125 was used as tracer and synthetic ET-1 or ET-3 as standard. The assay samples were incubated at $4^{\circ} \mathrm{C}$ in phosphate buffer $0.1 \mathrm{~mol} / \mathrm{L}$, pH 7.4 , containing $0.1 \%$ bovine serum albumin and $0.1 \%$ Triton $\mathrm{X}$ (Union Carbide Corp., Danbury, Conn.). The detection limit of the assays was $0.40 \mathrm{fmol} /$ tube (for further details of the radioimmunoassays, see Hemsén and associates ${ }^{20}$ ). For comparison, the tissue content of neuropeptide $Y$ and calcitonin gene-related peptide, which are present in perivascular sympathetic and afferent nerve terminals, respectively, was determined. ${ }^{21}$

Drugs. ET-1, ET-3, BQ-123, Ala ${ }^{1,3,11,15}$ ET-1, sarafotoxin $6 \mathrm{c}$, indomethacin, and L-NMMA were obtained from Peninsula Laboratories, Merseyside, England. Indomethacin was dissolved in absolute ethanol and the other compounds were dissolved in saline solution. Bosentan was generously provided by Dr. M. Clozel, F. Hoffman-La Roche, Basel, Switzerland.

Statistical evaluation. Values are given as means \pm standard error of the mean and expressed as percentage of contractions induced by a $127 \mathrm{mmol} / \mathrm{L}$ concentration of $\mathrm{K}^{+}$in control experiments. For statistical evaluation, the Mann-Whitney U test was used; $p<0.05$ was considered significant.

\section{Results}

Tissue content of ET-1 and ET-3. When quantified by radioimmunoassay, the content of ET-1 always exceeded that of ET-3 (Table I). The highest levels of both ETs were found in the LAD (1.14 \pm 0.13 and $0.27 \pm 0.05 \mathrm{pmol} / \mathrm{gm}$ for ET-1 and ET-3, respectively), followed in declining order by the ITA, PA, SV, and CV. The concentration of neuropeptide $Y$ was higher than that of the other peptides in all vessels investigated, whereas the distribution of calcitonin gene-related peptide more closely resembled that of ET-1 (Table I).

Coronary arteries. Potassium (127 $\mathrm{mmol} / \mathrm{L})$ caused contractions of the coronary arteries amounting to $2.1 \pm 0.25 \mathrm{mN}$. Exposure to ET-1 evoked a concentration-dependent sustained contraction of the arteries, which was markedly enhanced in vessels incubated with L-NMMA and indomethacin (Fig. 1). Incubation with BQ-123 or bosentan $\left(10^{-6}\right.$ to $\left.10^{-5} \mathrm{~mol} / \mathrm{L}\right)$ shifted the concentration-response curve to ET-1 to the right without any significant influence on the maximal response (Figs. 2 and 3 ). ET-3 evoked a minor contraction of the LAD, which was slightly increased by indomethacin and L-NMMA (Fig. 4) and significantly and concentration-dependently reduced by BQ-123 (Fig. 5). Sarafotoxin 6c also evoked contractions of the LAD, which was sensitive to BQ-123 (Fig. 6) and bosentan (not shown). No contractile effects were observed for Ala ${ }^{1,3,11,15} \mathrm{ET}-1$.

PAs. The PAs responded with a strong and sustained contraction $(1.74 \pm 0.26 \mathrm{mN})$ on exposure to potassium. ET-1 evoked a concentration-dependent, long-lasting contraction of the arteries that was not altered by incubation with L-NMMA and indomethacin (see Fig. 1). Incubation with BQ-123 or bosentan $\left(10^{-6}\right.$ to $\left.10^{-5} \mathrm{~mol} / \mathrm{L}\right)$ caused a rightward shift of the concentration-response curve (see Figs. 2 and 3). ET-3 also contracted the PA in a concentration-dependent manner (Fig. 4). This effect was not influenced by incubation with indomethacin and L-NMMA but was almost totally abolished after addition of BQ-123 (see Fig. 2). Sarafotoxin $6 c$ in concentrations up to $10^{-6} \mathrm{~mol} / \mathrm{L}$ did not evoke contraction in any of the PAs investigated (not shown). 

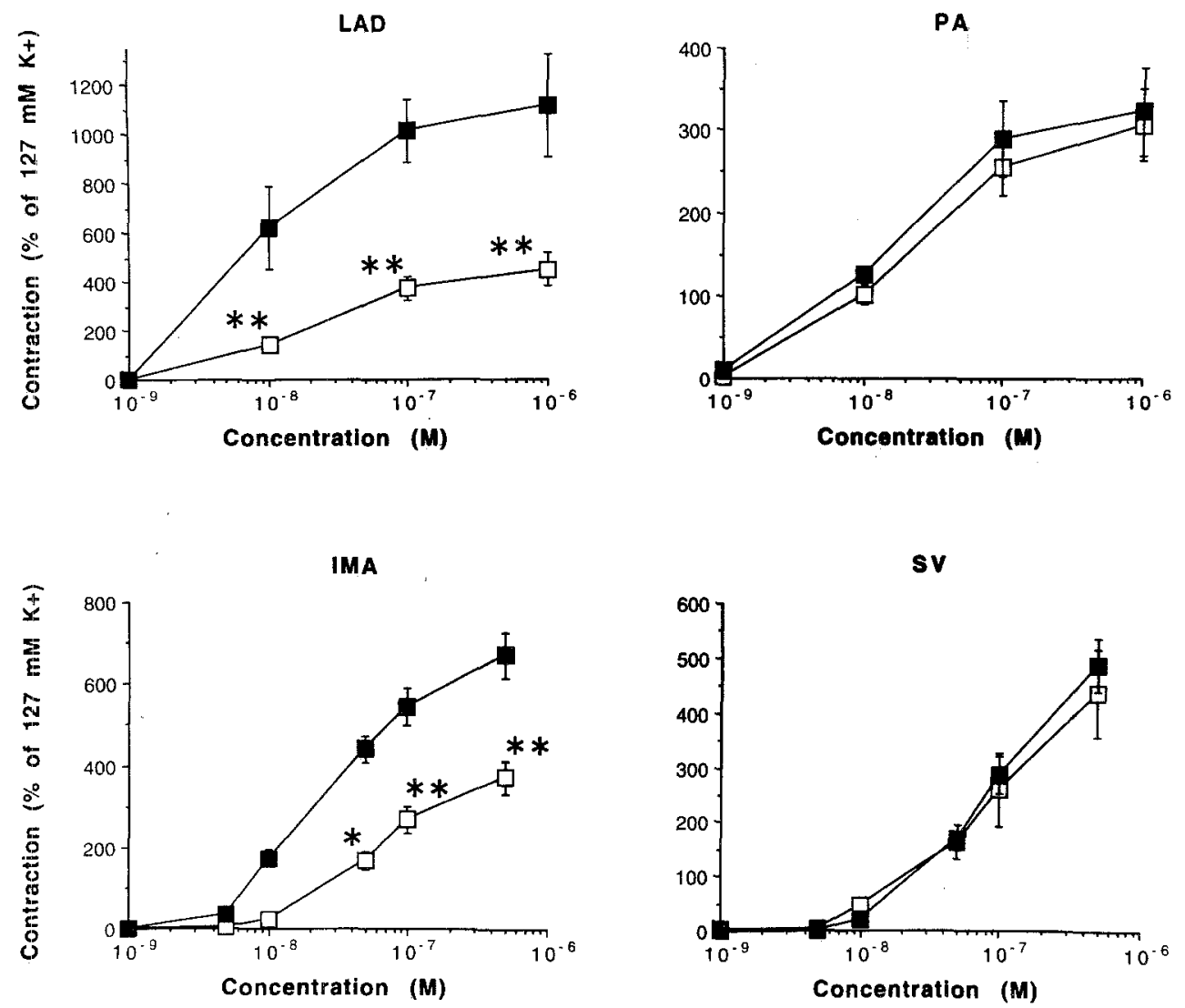

Fig. 1. Contractile effects of ET-1 in human LADs, PAs, ITAs, and SVs in control experiments (open squares) and after incubation with indomethacin $10^{-5} \mathrm{~mol} / \mathrm{L}$ and L-NMMA $10^{-4} \mathrm{~mol} / \mathrm{L}$ (black squares). Data are presented as means \pm standard error of the mean and are expressed as percentage of the maximal contraction induced by a $127 \mathrm{mmol} / \mathrm{L}$ concentration of $\mathrm{K}^{+} .{ }^{*} p<0.05$, ${ }^{*} p<0.01$, Mann-Whitney $\mathrm{U}$ test, compared with control experiments.

ITAs. In the ITA potassium exposure evoked a contraction of $1.34 \pm 0.22 \mathrm{mN}$. ET- 1 caused a concentration-dependent contraction of the ITA, which was increased after indomethacin and LNMMA incubation (see Fig. 1). Incubation with BQ-123, $10^{-6}$ and $10^{-5} \mathrm{~mol} / \mathrm{L}$, significantly reduced the response to ET-1 (see Fig. 2). ET-3 did not per se evoke any contractions of the ITA. However, after incubation with indomethacin and L-NMMA, ET-3 evoked a sustained BQ-123-sensitive, concentration-dependent contraction of the ITA (see Figs. 4 and 5).

SVs. Potassium exposure caused a strong contraction of the SV $(3.06 \pm 0.66 \mathrm{mN})$. Both ET-1 and ET-3 induced concentration-dependent contractions of the SV, which were not affected by incubation with indomethacin and L-NMMA (see Figs. 1 and 4). After addition of BQ-123, the response to ET-1 was shifted to the right, whereas the response to ET-3 was completely abolished (see Figs. 2 and 5).

\section{Discussion}

The important findings of this study are as follows: (1) The content of ET-1 exceeded that of ET-3 in all vessels investigated; (2) ET-induced contractions of the vessels investigated are primarily caused by activation of $\mathrm{ET}_{\mathrm{A}}$ receptors; (3) neither prostaglandin nor nitric oxide is produced in the $\mathrm{SV}$ or $\mathrm{PA}$ in response to ET, whereas production of both is induced in the ITA and LAD.

The coronary and pulmonary levels of ET-1-like immunoreactivity detected in the present study are similar to those previously reported for total ET-like immunoreactivity. ${ }^{20}$ The present study implies that the major portion of ET present in the vessels investigated is indeed ET-1. However, the use of an ET-3 antibody with no cross-reactivity to ET-1 


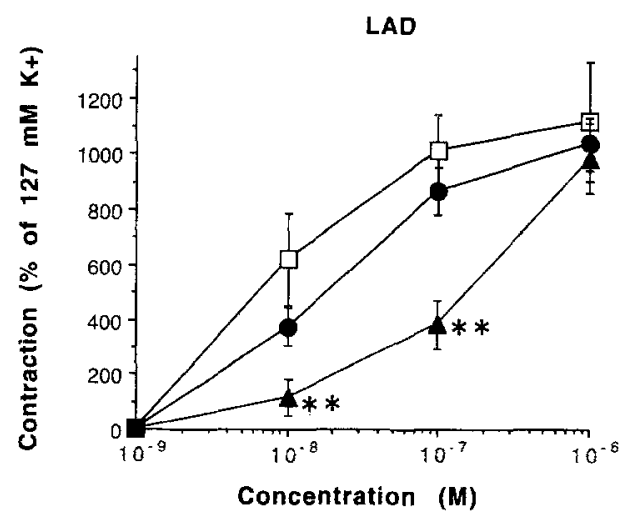

IMA

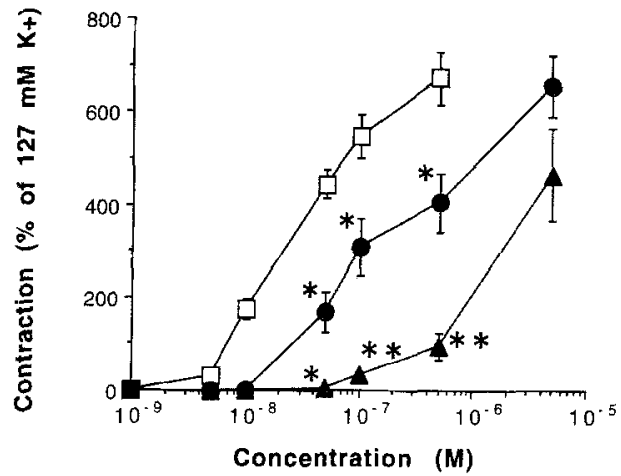

PA

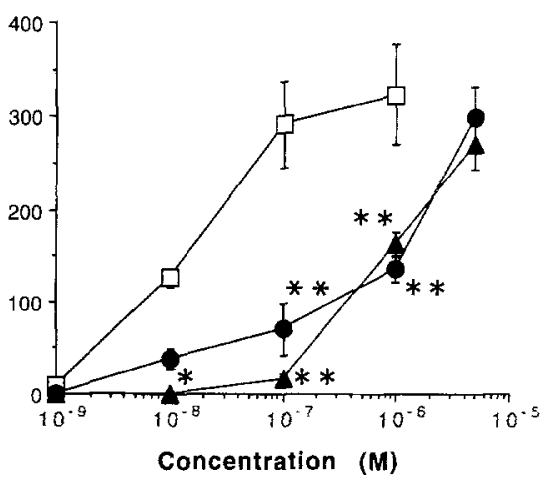

sv

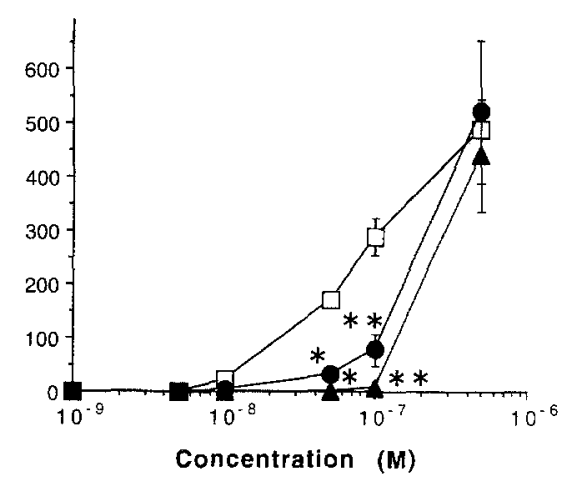

Fig. 2. Contractile effects of ET-1 in human LADs, PAs, ITAs, and SVs in control experiments (open squares) and after incubation with BQ-123 at $10^{-6} \mathrm{~mol} / \mathrm{L}$ (black circles) or $10^{-5} \mathrm{~mol} / \mathrm{L}$ (black triangles). Data are presented as means \pm standard error of the mean and are expressed as percentage of the maximal contraction induced by a $127 \mathrm{mmol} / \mathrm{L}$ concentration of $\mathrm{K}^{+} .{ }^{*} p<0.05,{ }^{*} p<0.01$, Mann-Whitney $\mathrm{U}$ test, compared with control experiments.

clearly demonstrates that ET-3 is also found in human vessels, in agreement with studies on rat cardiopulmonary tissue. ${ }^{22}$ However, because the vessels investigated were obtained from different patient groups with variability in age and sex, the relationship of ET content between the vessels should be interpreted with caution.

Our study demonstrates that selective antagonism of $\mathrm{ET}_{\mathrm{A}}$ receptors may be used to reveal functional receptor populations within vessels. Evidence for heterogeneity of ET receptor distribution of human coronary arteries has been presented. ${ }^{23}$ It was suggested that the ET receptor population may differ within the same coronary vessel, with $\mathrm{ET}_{\mathrm{A}}$ receptors predominantly in distal preresistant coronary arteries, whereas both $\mathrm{ET}_{\mathrm{A}}$ and $\mathrm{ET}_{\mathrm{B}}$ receptors were present in larger, proximal coronary arteries. According to the criteria used in that study, ${ }^{23}$ all the coronary vessels used in the present study would be classified as preresistant; thus our study, demonstrating only $\mathrm{ET}_{\mathrm{A}}$ receptors, does not confirm the earlier findings. However, it may well be that the ET-receptor population and functional effects differ with vascular diameter within certain vascular beds. There are reports of $\mathrm{ET}_{\mathrm{B}}$-mediated vasoconstriction of various vessels including canine and porcine coronary arteries, rabbit pulmonary arteries, and porcine PAs and pulmonary veins. ${ }^{10,24}$ The $\mathrm{ET}_{\mathrm{B}}$ receptor agonist sarafotoxin $6 \mathrm{c}$ was recently shown to contract the ITA, indicating the presence of contractile $\mathrm{ET}_{\mathrm{B}}$ receptors also in human arteries. ${ }^{25}$ Interestingly, Davenport and associates ${ }^{26}$ could not demonstrate any contractile activity in human coronary or pulmonary arteries of BQ-3020 or $\mathrm{Ala}^{1,3,11,15} \mathrm{ET}-1$, two compounds with affinity for the $\mathrm{ET}_{\mathrm{B}}$ receptors. In contrast, $60 \%$ of the arteries 
LAD

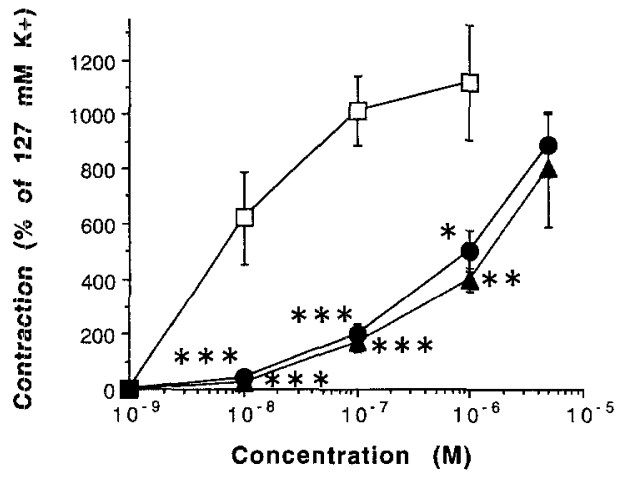

PA

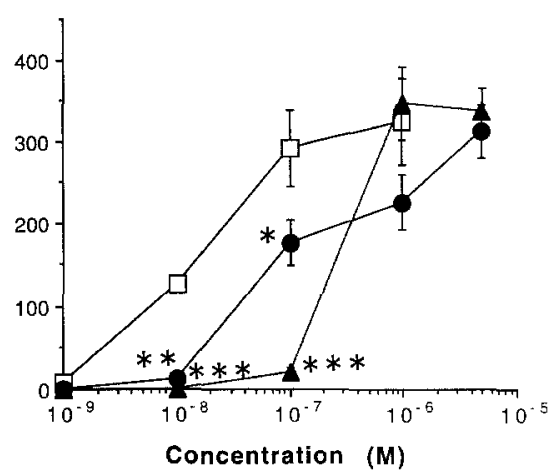

Fig. 3. Contractile effects of ET-1 in human LADs and PAs in control experiments (open squares) and after incubation with bosentan at $10^{-6} \mathrm{~mol} / \mathrm{L}$ (black circles) or $10^{-5} \mathrm{~mol} / \mathrm{L}$ (black triangles). Data are presented as means \pm standard error of the mean and are expressed as percentage of the maximal contraction induced by a $127 \mathrm{mmol} / \mathrm{L}$ concentration of $\mathrm{K}^{+} \cdot{ }^{*} p<0.05,{ }^{* *} p<0.01$, ${ }^{* * *} p<0.001$, Mann-Whitney $\mathrm{U}$ test, compared with control experiments.

LAD
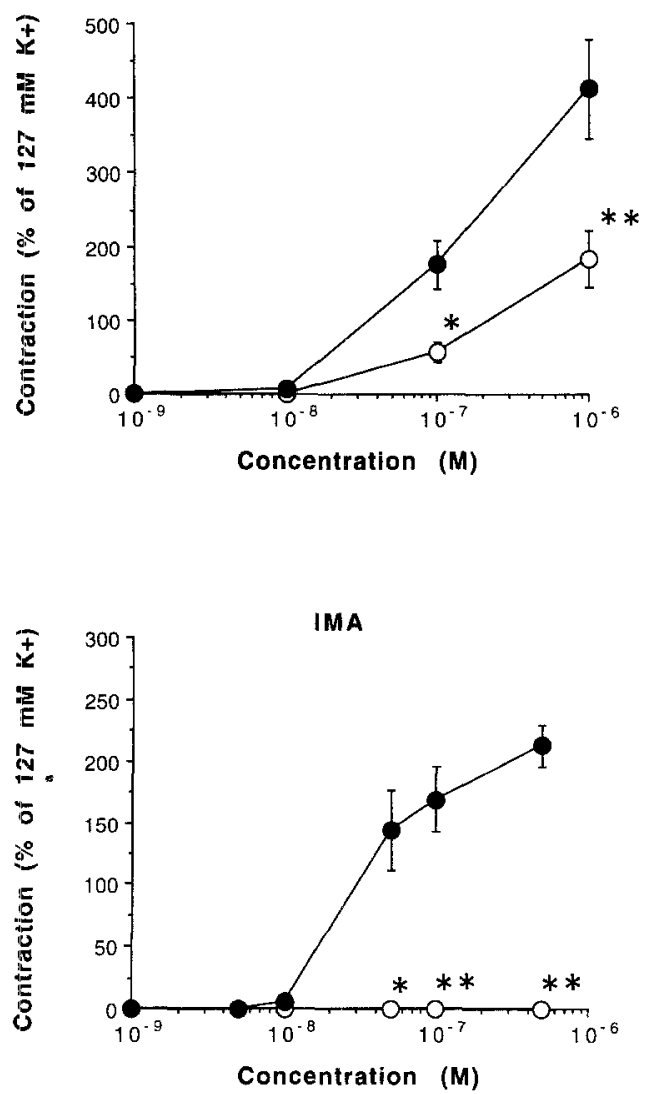

PA

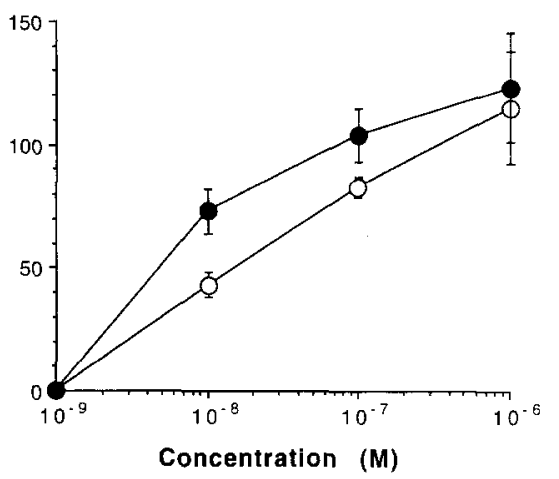

sv

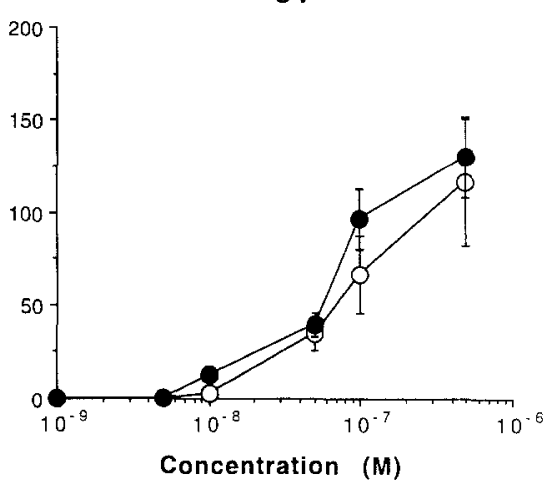

Fig. 4. Contractile effects of ET-3 in human LADs, PAs, ITAs, and SVs in control experiments (open circles) and after incubation with indomethacin $10^{-5} \mathrm{~mol} / \mathrm{L}$ and $\mathrm{L}-\mathrm{NMMA} 10^{-4} \mathrm{~mol} / \mathrm{L}$ (black circles). Data are presented as means \pm standard error of the mean and are expressed as percentage of the maximal contraction induced by a $127 \mathrm{mmol} / \mathrm{L}$ concentration of $\mathrm{K}^{+} \cdot{ }^{*} p<0.05,{ }^{*} p<0.01$, Mann-Whitney $\mathrm{U}$ test, compared with control experiments. 
LAD

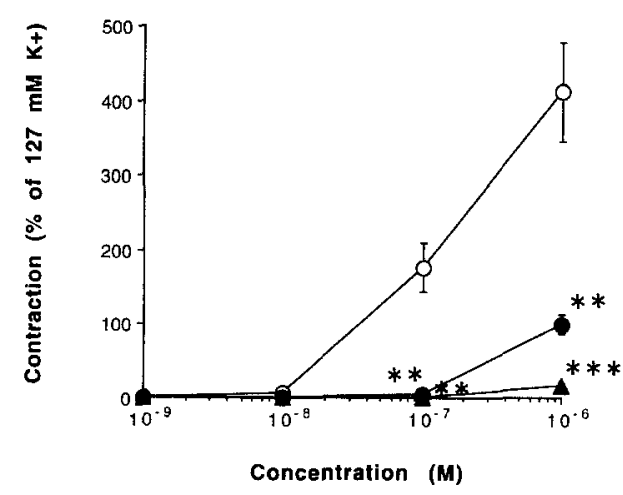

IMA

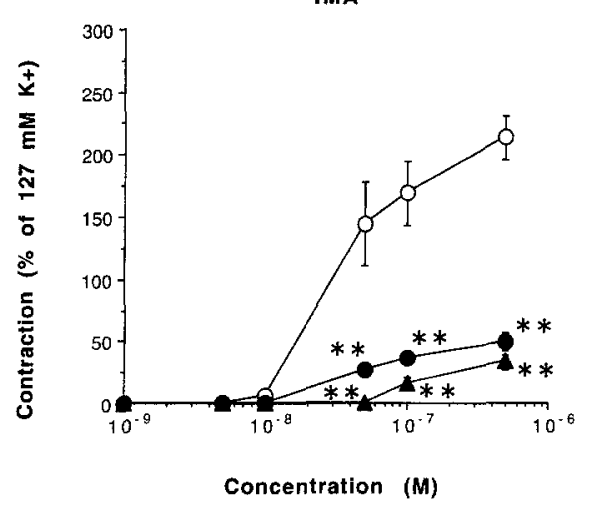

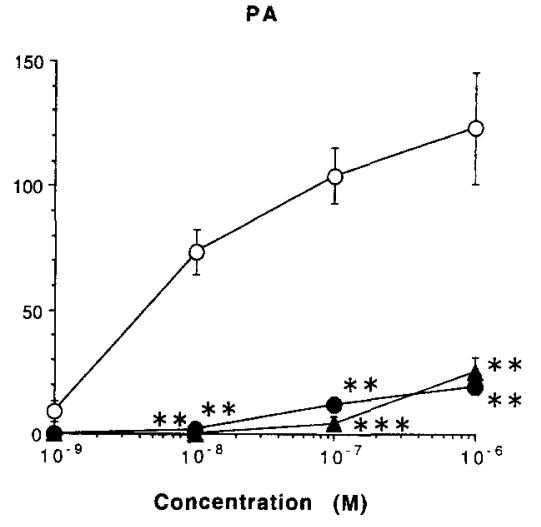

sv

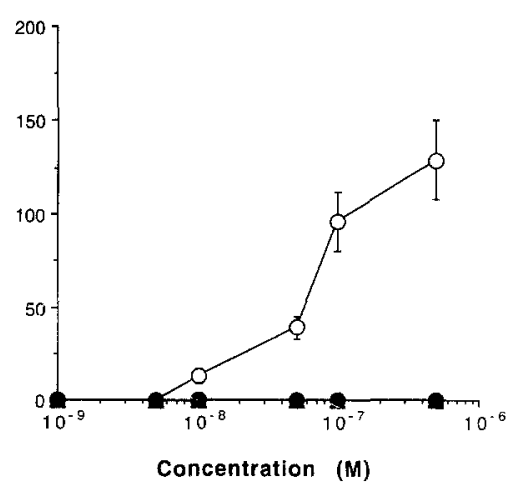

Fig. 5. Contractile effects of ET-3 in human LADs, PAs, ITAs, and SVs in control experiments (open circles) and after incubation with BQ-123 at $10^{-6} \mathrm{~mol} / \mathrm{L}$ (black circles) or $10^{-5} \mathrm{~mol} / \mathrm{L}$ (black triangles). Data are presented as means \pm standard error of the mean and are expressed as percentage of the maximal contraction induced by a $127 \mathrm{mmol} / \mathrm{L}$ concentration of $\mathrm{K}^{+} .{ }^{*} p<0.05,{ }^{* *} p<0.01,{ }^{* * *} p<0.001$, Mann-Whitney U test, compared with control experiments.

responded to sarafotoxin $6 c^{27}$ In accord, we observed a concentration-dependent vasoconstriction of the LAD on exposure to sarafotoxin $6 \mathrm{c}$ but not $\mathrm{Ala}^{1,3,11,15} \mathrm{ET}-1$. Moreover, the response to sarafotoxin $6 \mathrm{c}$ was attenuated equally by BQ-123 and bosentan. The magnitude of ET-1 contractions was twofold to fivefold greater than that of ET-3-induced contractions in the presently studied vessels, indicating that the observed vasoconstriction is mediated predominantly by the $\mathrm{ET}_{\mathrm{A}^{\mathrm{T}}}$-receptor subtype. This is further substantiated by the competitive antagonism by the selective $\mathrm{ET}_{\mathrm{A}}$-receptor blocker BQ-123 on the response to ET-1 and ET-3 in all investigated vessels. Although it has recently been reported that $\mathrm{ET}_{\mathrm{B}}$-mediated vasoconstriction is present in the pulmonary circulation of various species, ${ }^{10,24}$ no effects of sarafotoxin $6 \mathrm{c}$ were observed in the PA in the present study. Marked species differences are obviously present, but the receptor population may also differ in different vascular beds in the same species. Thus human kidney cortex contains $\mathrm{ET}_{\mathrm{A}}$ and $\mathrm{ET}_{\mathrm{B}}$ receptors in a $30: 70$ ratio, ${ }^{28}$ whereas the ratio in the human PA is 93:7. ${ }^{29}$ Finally, the selectivity of agonists and antagonists is not absolute but depend on the concentrations used.

It is likely that the vasodilatation and the putative vasoconstriction caused by activation of $\mathrm{ET}_{\mathrm{B}}$ receptors are mediated through different receptor subtypes, $\mathrm{ET}_{\mathrm{B} 1}$ and $\mathrm{ET}_{\mathrm{B} 2}$, present on the vascular endothelium and smooth muscle cells, respectively. ${ }^{11,12}$ Subsequently, formation of prostacyclin or nitric oxide, or both, may counteract the vasoconstrictor effects of $\mathrm{ET}_{\mathrm{B} 2}$-receptor activation. The presently observed response to ET-1 in the LAD was markedly enhanced after inhibition of prosta- 


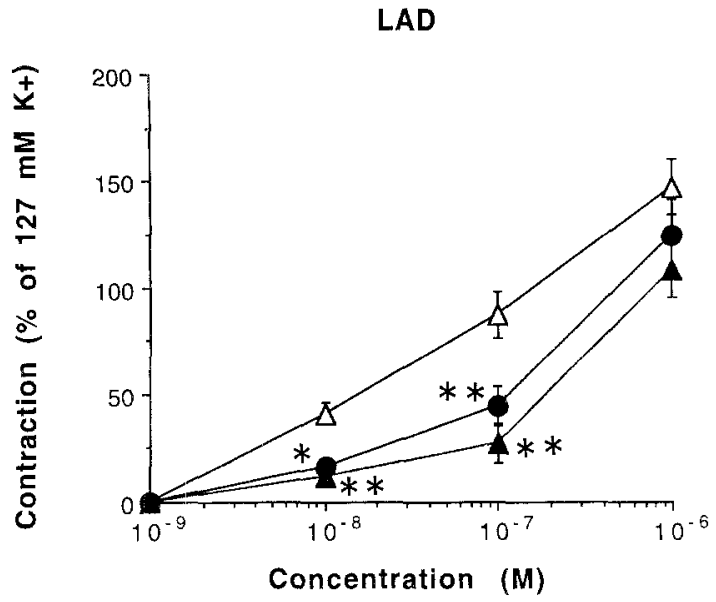

Fig. 6. Contractile effects of sarafotoxin $6 c$ on LADs in control experiments (open triangles) and after incubation with BQ-123 at $10^{-6} \mathrm{~mol} / \mathrm{L}$ (black circles) or $10^{-5} \mathrm{~mol} / \mathrm{L}$ (black triangles). Data are presented as means \pm standard error of the mean and are expressed as percentage of the maximal contraction induced by a $127 \mathrm{mmol} / \mathrm{L}$ concentration of $\mathrm{K}^{+} . * p<0.05,{ }^{* *} p<0.01$, Mann-Whitney $\mathrm{U}$ test, compared with control experiments.

glandin and nitric oxide formation. Furthermore, ET-3 contracted the ITA only after addition of indomethacin and L-NMMA. These findings suggest that formation of prostacyclin or nitric oxide on ET-receptor activation are important determinants of the functional response to ET exposure in the ITA and LAD, but not in the PA or SV, although the investigated vessels respond to exogenous nitric oxide release from drugs such as nitroprusside. ${ }^{18,24,25,31}$ Both prostacyclin formation and nitric oxide release are higher in the ITA than in the SV. It is widely known that the ITA has a higher capacity of endothelium-dependent vasodilatation than does the SV. ${ }^{30,31}$ The lack of influence of nitric oxide and prostaglandin inhibition on the ET effect in the PA is consistent with findings in porcine PAs ${ }^{18}$ and the report that more than $90 \%$ of the ET receptors in the human lung belong to the $\mathrm{ET}_{\mathrm{A}}$ subgroup. ${ }^{29}$

Autologous graft vasospasm may be an important factor in myocardial ischemia and postoperative morbidity after coronary revascularization procedures. ${ }^{32}$ The vasoconstrictor peptide ET is known to be released during bypass grafting ${ }^{14,15}$ and may play some role in the development of vasospasm. On the basis of the present study, further investigation should be performed to evaluate whether selective inhibition of $\mathrm{ET}_{\mathrm{A}}$ receptors may be clinically bene- ficial in preventing ET-induced graft spasm after cardiac operations.

The technical assistance of M. Utahs, M. Runsiö, M. Stensdotter, and C. Nihlén is gratefully acknowledged.

\section{REFERENCES}

1. Lüscher TF, Vanhoutte PM. Endothelium-dependent responses in human blood vessels. Trends Pharmacol Sci 1988;9:181-4.

2. Hickey KA, Rubanyi G, Paul RJ, Highsmith RF. Characterization of a coronary vasoconstrictor produced by cultured endothelial cells. Am J Physiol 1985;248:C550-6.

3. Yanagisawa M, Kiruhara H, Kimura S, et al. A novel potent vasoconstrictor peptide produced by vascular endothelial cells. Nature 1988;332:411-5.

4. Inoue A, Yanagisawa M, Kimura S, Kasuya Y, Miyashi T, Goto K, et al. The human endothelin family: three structurally and pharmacologically distinct isopeptides predicted by three separate genes. Proc Natl Acad Sci 1989;86:2863-7.

5. Lippton H, Goff J, Hyman A. Effects of endothelin in the systemic and renal vascular beds in vivo. Eur J Pharmacol 1988;155:197-9.

6. Wright CE, Fozard JR. Regional vasodilatation is a prominent feature of the haemodynamic response to endothelin in anaesthetized, spontaneously hypertensive rats. Eur J Pharmacol 1988;155:201-3.

7. Ishikawa T, Yanagisawa M, Kimura S, Goto K, Masaki T. Positive inotropic action of novel vasoconstrictor peptide endothelin on guinea-pig atria. Am J Physiol 1988;255: H970-3.

8. Ishikawa T, Yanagisawa M, Kimura S, Goto K, Masaki T. Positive chronotropic effects of endothelium: a novel endothelium-derived vasoconstrictor peptide. Pflugers Arch 1988; 413:108-10.

9. Franco-Cereceda A, Matran R, Lou Y-P, Lundberg J. Occurrence and effects of endothelin in guinea-pig cardiopulmonary tissue. Acta Physiol Scand 1990;137:539-47.

10. Bax WA, Saxena PR. The current endothelin receptor classification: time for reconsideration. Trends Pharmacol Sci 1994;15:379-86.

11. Warner TD, Allcock GH, Mickley EJ, Vane JR. Characterization of endothelin receptors mediating the effects of the endothelin/sarafotoxin peptides on autonomic neurotransmission in the rat vas deferens and guinea-pig ileum. Br J Pharmacol 1993;110:783-9.

12. Clozel M, Breu V, Gray GA, et al. Pharmacological characterization of bosentan, a new potent orally active nonpeptide endothelin receptor antagonist. J Pharmacol Exp Ther 1994; 270:228-35.

13. Williams DL, Jones KL, Pettibone DJ, Lis EV, Clineschmidt BV. Sarafotoxin 6c: an agonist which distinguishes between endothelin receptor subtypes. Biochem Biophys Res Commun 1991;175:556-61.

14. Franco-Cereceda A, Ericsson A, Sellei P, Vaage J, Valen G, Lundberg JM. Endothelin release at reperfusion of the porcine ischaemic heart in relation to noradrenaline and neuropeptide Y. Acta Physiol Scand 1994;151:541-3.

15. Franco-Cereceda A, Barr G, Öwall A, Liska J, Lundberg JM. Is endothelin-1 release at reperfusion of the ischaemic hu- 
man heart due to cold-induced displacement of endothelin from binding sites? Eur J Pharmacol 1995;279:105-7.

16. Franco-Cereceda A. ET- and NPY-induced vasoconstriction of human coronary arteries in vitro. Br J Pharmacol 1989;97: 968-72.

17. Costello K, Stewart DJ, Baffour R. Endothelin is a potent constrictor of human vessels used in coronary revascularization surgery. Eur J Pharmacol 1990;186:311-4.

18. Zellers TM, McCormick J, Wu Y. Interaction among ET-1, endothelium-derived nitric oxide, and prostacyclin in pulmonary arteries and veins. Am J Physiol 1994;267:H139-47.

19. Ihara M, Nuguchi K, Saeki T, et al. Biological profiles of highly potent novel endothelin antagonists selective for the $\mathrm{ET}_{\mathrm{A}}$ receptor. Life Sci 1992;50:247-55.

20. Hemsén A, Franco-Cereceda A, Matran R, Rudehill A, Lundberg JM. Occurrence, specific binding sites and functional effects of endothelin in human cardiopulmonary tissue. Eur J Pharmacol 1990;191:319-28.

21. Franco-Cereceda A. Calcitonin gene-related peptide and human epicardial coronary arteries: presence, release and vasodilator effects. Br J Pharmacol 1991;102:506-10.

22. Matsumoto H, Suzuki N, Onda H, Fujino M. Abundance of endothelin-3 in rat intestine, pituitary gland and brain. Biochem Biophys Res Commun 1989;164:74-80.

23. Godfraind T. Evidence for heterogeneity of endothelin receptor distribution in human coronary arteries. Br J Pharmacol 1993;110:1201-5.

24. Davenport AP, Maguire JJ. Is endothelin-induced vasoconstriction mediated only by $\mathrm{ET}_{\mathrm{A}}$ receptors in humans? Trends Pharmacol Sci 1994;15:9-11.
25. Seo B, Oemar BS, Siebenmann R, Segesser L, Lüscher TF. Both $\mathrm{ET}_{\mathrm{A}}$ and $\mathrm{ET}_{\mathrm{B}}$ receptors mediate contraction to endothelin-1 in human blood vessels. Circulation 1994;89:1203-8.

26. Davenport AP, O'Reilly G, Molenaar P, Maguire JJ, Kuc RE, Sharkey A, et al. Human endothelin receptors characterized using reverse transcriptase-polymerase chain reaction, in situ hybridization, and subtype-selective ligands BQ123 and BQ-3020: evidence for expression of $\mathrm{ET}_{\mathrm{B}}$ receptors in human vascular smooth muscle. J Cardiovasc Pharmacol 1993;22:S22-5.

27. Maguire JJ, Davenport AP. Endothelin-induced vasoconstriction in human isolated vasculature is mediated predominantly via activation of $\mathrm{ET}_{\mathrm{A}}$ receptors. $\mathrm{Br} \mathrm{J}$ Pharmacol 1993;110:47P.

28. Nambi P, Pullen M, Wu HL, Aiyar N, Ohistein EH, Edwards RM. Identification of endothelin-receptor subtypes in human renal cortex and medulla using subtype-selective ligands. Endocrinology 1992;131:1081-6.

29. Fukuroda T, Kobayashi M, Ozaki S, et al. Endothelin receptor subtypes in human versus rabbit pulmonary arteries. J Appl Physiol 1994;76:1976-82.

30. Sala A, Rona P, Pompilio G, et al. Prostacyclin production by different human grafts employed in coronary operations. Ann Thorac Surg 1994;57:1147-50.

31. Pearson PJ, Evora PRB, Schaff HV. Bioassay of EDRF from internal mammary arteries: implications for early and late bypass graft patency. Ann Thorac Surg 1992;54:1078-84.

32. Sarubu MR, McClung JA, Fuss A, Reed GE. Early postoperative spasm in left internal mammary artery bypass grafts. Ann Thorac Surg 1987;44:199-200. 